TEGAR 4 (1) (2020) 5-10
Journal of Teaching Physical Education in Elementary School
Available online at :
https://ejournal.upi.edu/index.php/tegar/article/view/28639
DOI: https://doi.org/10.17509/tegar.v4i1.28639

\title{
Nutrition Education for Preventing Stunting in Elementary Schools: A Systematic Review
}

\section{Syifa F. Syihab, Isti Kumalasari}

Universitas Pendidikan Indonesia, Indonesia

\begin{tabular}{|c|c|}
\hline Article Info & Abstract \\
\hline $\begin{array}{l}\text { Article History: } \\
\text { Received : August } 2020 \\
\text { Accepted : September } 2020 \\
\text { Available Online : October } 2020 \\
\text { Keywords: } \\
\text { education, elementary school, nutri- } \\
\text { tion, stunting. }\end{array}$ & $\begin{array}{l}\text { Stunting has become a major problem in developing countries. The government has } \\
\text { formulated various strategies to decrease the stunting prevalence in Indonesia. How- } \\
\text { ever, the number of programs to be implemented on the school aged children is } \\
\text { scarce. Stunting in the school age can affect the productivity, motor development, and } \\
\text { vulnerability from communicable diseases. The purpose of this study was to identify } \\
\text { journals related to the nutrition education in preventing stunting in elementary } \\
\text { schools. The study was a systematic review about nutrition education to prevent stunt- } \\
\text { ing in elementary school. There were } 5 \text { articles analyzed from the result of Google } \\
\text { Scholar search, published from } 2018 \text { to } 2020 \text {. The review focused on the type of in- } \\
\text { tervention, goal, and effectiveness of the intervention. The result of the study showed } \\
\text { that nutrition education could improve a short term knowledge. However, it had not } \\
\text { been able to change the behavior and practice of healthy dietary habit. Nutrition edu- } \\
\text { cation given to the teachers could improve their skills in assessing student nutritional } \\
\text { status, thus an early detection can be administered well. A more comprehensive inter- } \\
\text { vention, besides nutrition education, in preventing stunting in elementary school is } \\
\text { needed. }\end{array}$ \\
\hline
\end{tabular}




\section{INTRODUCTION}

Stunting is a chronic nutritional problem that often occurs in children. This condition is characterized by the body height below $-2 \mathrm{SD}$ of the Child Growth Standard median. In 2016, about 154.8 million children in the world are stunting (WHO, 2018). Stunting is a cumulative process of delayed growth in children that generally occurs before they are three year old, and continues until school age (ElFatah \& Abu-Elenin, 2019). So far, the prevalence and incidence of stunting has only highlighted the problem of children under five. In fact, nutrition problems in school age children occur in many developing and transition countries with more than $20 \%$ of the cases. Underweight and emaciation are most pronounced in Southeast Asia and Africa. Meanwhile, for school age children from Latin America the prevalence is generally lower with less than 10\% (Best et al., 2010).

The results of the 2013 Riskesdas for children aged 5-12 years show that the stunting rate in Indonesia is $30.7 \%$ (12.3\% are categorized very short and $18.4 \%$ are short). The province with the lowest stunting prevalence is DI Yogyakarta $(14,(\%)$ and the highest is Papua (34.5\%) (Badan Penelitian dan Pengembangan Kesehatan, 2013). In 2018 there is a decrease in the stunting rate, although it is still higher than the WHO standard at $20 \%$. The results of Basic Health Research 2018 reported that the prevalence of nutritional status (height/age) in children aged $5-12$ is $23.6 \%$ (6.7\% very short and $16.9 \%$ short). The number of boys $(24.5 \%)$ who experienced stunting is higher than girls $(22.8 \%)$. Based on demographic condition, it is found that children living in rural areas $(28.8 \%)$ are more prone to experiencing stunting than children living in urban areas (19\%). The province with the lowest stunting prevalence is DKI Jakarta (10.8\%) and the highest is East Nusa Tenggara (41.1\%) (Badan Penelitian dan Pengembangan Kesehatan, 2018).

In Indonesia and some other developing countries, stunting is categorized as a chronic nutritional problem caused by a number of factors, including socio-economic condition, nutritional adequacy of pregnant women, history of disease during infancy, and lack of nutritional intake for infants (Pusdatin Kemenkes, 2018). Stunting in children will affect their productivity later on in adulthood. In addition, this condition has the potential to lead to imperfect growth and development potential, low motor skills and productivity, and a higher risk of suffering from infectious diseases (Bloem et al., 2013).

Stunting handling in Indonesia has been pursued across sectors through the National Movement for the First Thousand Days of Life. The first thousand days of life start from the first day of pregnancy until the child is 24 months old. In addition, the Ministry of National Development Planning/ National Development Planning Agency (PPN/ Bappenas) also launched an integrated stunting reduction intervention in districts/regions. Efforts to reduce stunting are carried out through two interventions, namely to specify in addressing direct causes and be sensitive to address indirect causes. In addition, supporting prerequisites are needed, including political and policy commitment, government and cross-sector involvement, and the ability in the implementation. However, in global scope, the handling of stunting experiences several obstacles including difficult coordination, weak strategies, lack of interest from stakeholders, weak stakeholder networks, weak power in determining policies, unequal positions in collaboration, limited human resources and budget constraints (Morris et al., 2008). So far, most research has focused on malnutrition of children under five, while school age children are often neglected. Several studies show that treatment and nutritional care programs combined with other interventions in children aged 2 or 3 have a better effect than in older children of 5-6 year old (Armecin G et al., 2006). However, school becomes a platform/ institution where we can provide integrated interventions, such as providing nutritious food or snacks, supplements/ fortification, infectious disease control, health socialization, and life skill education, to improve the health and nutrition level of school children (Best et al., 2010).

One of the attempts to control stunting cases is through health and nutrition education. Health education cannot be separated from the media. Through media, the messages conveyed can be more interesting and easier to understand. The target can learn the message and decide to adopt some positive behaviors. A number of media is used in providing health education for elementary school children, for example, leaflets, videos, films, puzzle games, snake and ladder games as well as story books (Niman, 2017). 


\section{METHOD}

The data used in this study were articles published through online media and could be downloaded in full articles (full text download). The data was collected using the google scholar search engine database. The keyword used was the prevention of stunting in primary schoola. Data search was carried out from 1 to 10 September 2020.

Inclusion criteria Articles from journals in Indonesia is (1) Articles with research locations in Indonesia; (2) Articles with experimental methods, both true and quasi-experimental; (3) The interventions provided were in the form of nutrition education.

The analysis procedure in a systematic review went through the following stages: 1) Assessing the validity of each article. Things to consider included: the study to be reviewed must clearly and specifically pose the research question. The study must also present the research subject, the type of intervention, the experimental approach and method used, and the results of the intervention; 2) Compiling a table of lists and characteristics of the articles; 3) Analyzing the relationship between various aspects and conducting elaboration on the theory and research of stunting in school age children.

\section{RESULT AND DISCUSSION}

The search for articles with the keyword "primary school stunting prevention" found 1,380 articles in both journals and research results. The search results for journals with the keyword the prevention of stunting in primary schools were found as many as 13 articles. The search was narrowed down to journals that used the experimental method, obtained 9 articles and those using nutrition education interventions were 5 articles. The article tracing chart is depicted in Figure 1. The journals were analyzed using a quasi-experimental method with two designs, namely one group pre-posttest (3 journals) and a pre-posttest with control design ( 2 journals). The control group design allowed analyzing the effect of the intervention through comparison with other groups that did not get the intervention.

The five journals in Table 1 show that the targets of nutrition education in elementary schools can be aimed at students ( 3 journals), teachers (1 journal) and parents (1 journal). The health of students in schools cannot be separated from the socioecological state and the environment where they live. The family and community where the student lives and the environment in which the school is located are ecological entities that cannot be separated. School health programs should also be directed at the general context, not just on individual health condition. School health programs using a multicomponent approach tend to be more successful when compared to using only students as targets for activities. The other relevant components are the principal, teachers, staff, school guards, canteen keepers, including parents of students (JohnAkinola, 2014.

Family is one of the health promotion targets at schools. Families are considered the supporter of the success of health promotion programs in schools (support side) as well as the party who benefit from taking place in school health promotion (impact

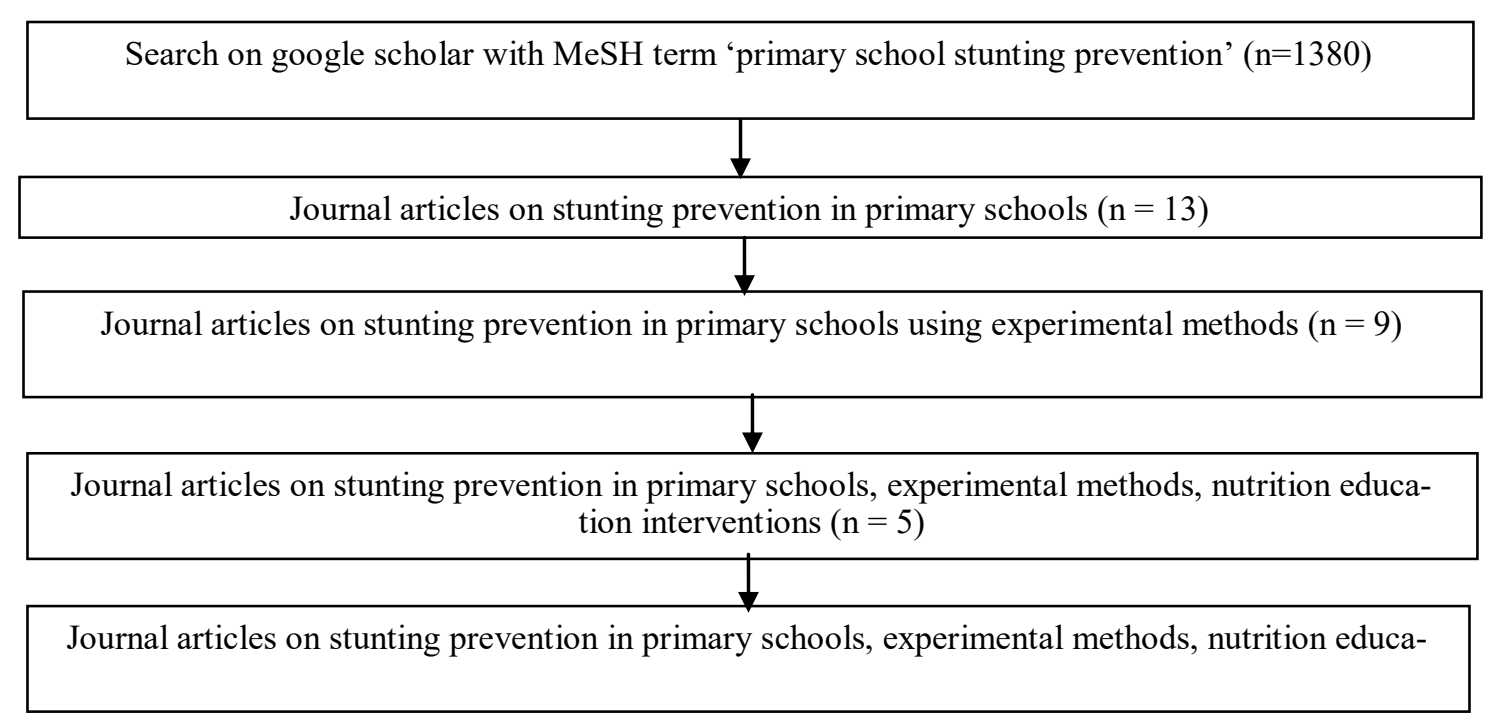

Figure 1. Article search systematics 
side) (Pusat Promosi Kesehatan, 2008).

Media is used as a tool in health promotion. The media can be seen, heard, touched, smelled or tasted to facilitate communication and the delivery of information. The educational media used are different. For students, education is provided through short films, puzzles and counseling on healthy snacks. For teachers, there are health services on stunting and balanced nutrition as well as training on nutritional status. Meanwhile, parents are given training on family empowerment to increase family support and empowerment in identifying the nutritional status of children.

Table 1. Characteristics of journal articles

\begin{tabular}{|c|c|c|c|c|}
\hline $\begin{array}{l}\text { Study } \\
\text { number }\end{array}$ & Researcher & Intervention & $\begin{array}{l}\text { Number and } \\
\text { characteristics }\end{array}$ & Study results \\
\hline 1 & $\begin{array}{l}\text { (Oktaviani \& } \\
\text { Sunarti, 2020) }\end{array}$ & $\begin{array}{l}\text { Nutrition education with } \\
\text { puzzle media. The design } \\
\text { used was a quasi- } \\
\text { experimental with a pre- } \\
\text { posttest control group. Stu- } \\
\text { dents were asked to compile } \\
\text { a puzzle of balanced nutri- } \\
\text { tion. }\end{array}$ & $\begin{array}{l}\text { A total of } 47 \\
\text { students } \text { of } \\
\text { grade IV SD in } \\
\text { Samarinda each } \\
\text { were taken as } \\
\text { intervention and } \\
\text { control groups } \\
\text { using simple } \\
\text { random sam- } \\
\text { pling technique. }\end{array}$ & $\begin{array}{l}\text { There were differences in } \\
\text { the level of knowledge } \\
\text { before and after the inter- } \\
\text { vention in the interven- } \\
\text { tion group, but there was } \\
\text { no difference in the con- } \\
\text { trol group. There was no } \\
\text { difference in attitudes in } \\
\text { the two groups before and } \\
\text { after the intervention. }\end{array}$ \\
\hline 2 & $\begin{array}{c}\text { (Amandyakissya } \\
\text { et al., 2019) }\end{array}$ & $\begin{array}{l}\text { Nutrition education through } \\
\text { screening of short films } \\
\text { about healthy snacks. The } \\
\text { design used was one group } \\
\text { pre-posttest design. Students } \\
\text { watched short films with the } \\
\text { duration of } 20 \text { minutes for } 3\end{array}$ & $\begin{array}{l}60 \text { elementary } \\
\text { students in } \\
\text { grades } 4 \text { and } 5 \\
\text { in Ambon with } \\
\text { total sampling } \\
\text { technique }\end{array}$ & $\begin{array}{l}\text { The results of the Wilcox- } \\
\text { on analysis showed a sig- } \\
\text { nificant difference in } \\
\text { knowledge from before } \\
\text { and after watching films } \\
\text { about healthy snacks. }\end{array}$ \\
\hline 3 & $\begin{array}{c}\text { (Fitri et al., } \\
2020)\end{array}$ & $\begin{array}{l}\text { This study used a quasi- } \\
\text { experimental design with a } \\
\text { non-equivalent group pretest } \\
\text { posttest design. Students } \\
\text { were given nutrition educa- } \\
\text { tion about healthy traditional } \\
\text { snacks. }\end{array}$ & $\begin{array}{l}\text { The sample was } \\
33 \text { elementary } \\
\text { students in Ban- } \\
\text { da Aceh }\end{array}$ & $\begin{array}{l}\text { The results of the analysis } \\
\text { using the dependent t-test } \\
\text { showed that there were } \\
\text { significant differences in } \\
\text { knowledge, but not on the } \\
\text { snacking behavior of stu- } \\
\text { dents before and after }\end{array}$ \\
\hline 4 & $\begin{array}{l}\text { (Sefrina \& El- } \\
\text { vandari, 2020) }\end{array}$ & $\begin{array}{l}\text { The design used was a quasi } \\
\text {-experiment with one group } \\
\text { pre-posttest design. Nutri- } \\
\text { tional status assessment and } \\
\text { balanced menu training with } \\
\text { lecture and demonstration } \\
\text { methods were conducted. } \\
\text { The variables assessed were } \\
\text { knowledge of stunting and } \\
\text { the practice of assessing }\end{array}$ & $\begin{array}{l}\text { The research } \\
\text { sample was } 30 \\
\text { elementary } \\
\text { school teachers } \\
\text { in Karawang. }\end{array}$ & $\begin{array}{l}\text { The training increased } \\
\text { knowledge about stunting } \\
\text { and skills to assess nutri- } \\
\text { tional status }\end{array}$ \\
\hline 5 & $\begin{array}{l}\text { (Hastuti \& Ha- } \\
\text { nim, 2018) }\end{array}$ & $\begin{array}{l}\text { This study used a semi- } \\
\text { experimental design with a } \\
\text { pre-posttest design with con- } \\
\text { trol group. The intervention } \\
\text { group was given a family } \\
\text { empowerment module. The } \\
\text { variables analyzed were diet, } \\
\text { family empowerment, and } \\
\text { children's BMI. The target of } \\
\text { intervention was parents of } \\
\text { elementary school children }\end{array}$ & $\begin{array}{l}\text { A total of } 172 \\
\text { respondents } \\
\text { with purposive } \\
\text { sampling tech- } \\
\text { nique in Malang } \\
\text { was taken }\end{array}$ & $\begin{array}{l}\text { Intervention increased } \\
\text { community empower- } \\
\text { ment. The results of the } \\
\text { analysis using Mann } \\
\text { Whitney show that there } \\
\text { were differences in diet, } \\
\text { BMI and family empow- } \\
\text { erment between the inter- } \\
\text { vention and control } \\
\text { groups. }\end{array}$ \\
\hline
\end{tabular}


The analysis results of the five journals reveal the variables that can be influenced, which are knowledge and skill improvement in assessing nutritional status. Two other important variables, attitude and practice/behavior, showed no difference before and after the intervention. Changes in knowledge variables occur as a direct result of intervention, but practice is the accumulation of a person's knowledge, attitudes and beliefs over a long period of time. Thus, continuous intervention is needed to increase awareness and preventive measures (PazSoldán et al., 2015).

Although changes in attitudes and practices have not been seen, new behavior or behavioral adoption on knowledge tends to be long lasting than those that are not based on knowledge (Notoatmodjo, 2010). Changes in knowledge can be done through educational interventions including counseling (Suryawan, 2019). The increase in teacher knowledge is expected to divert their attitudes and behavior, which can be disseminated to students and parents later on.

\section{CONCLUSION}

The research results showed that nutrition education could increase short-term knowledge. However, it has not been able to divert attitudes and behavior/practices of healthy consumption pattern. Nutrition education provided to teachers can improve skills in assessing the nutritional status of students in order to be able to make early detection better. A more comprehensive intervention is needed, apart from nutrition education, to prevent stunting in primary schools.

\section{REFERENCES}

Amandyakissya, T., Maelissa, S. R., \& Lilipory, M. (2019). Media Film Pendek Berhasil Meningkatkan Pengetahuan Anak Usia Sekolah dalam Memilih Jajanan Sehat. Moluccas Health Jurnal, 1(2), 90-96. http://ojs.ukim.ac.id/ index.php/natuna/article/viewFile/131/106

Armecin, G., Behrman, J. R., Ghuman, S., Gultiano, S., King, E. M., \& Lee, N. (2006). Early Childhood Development through an Integrated Program: Evidence from the Philippines. Impact Evaluation Series No. 2. World Bank Policy Research Working Paper 3922IE. World Bank Publications.

Badan Penelitian dan Pengembangan Kesehatan. (2013). Riset Kesehatan Dasar (Riskesdas)
2013.

Badan Penelitian dan Pengembangan Kesehatan. (2018). Laporan Riset Kesehatan Dasar 2018.

Best, C., Neufingerl, N., Geel, L. van, Briel, T. van den, \& Osendarp, S. (2010). The nutritional status of school-aged children: Why should we care? Food and Nutrition Bulletin, 400-417.

Bloem, M. W., de Pee, S., Hop, L. T., Khan, N. C., Laillou, A., Minarto, Moench-Pfanner, R., Soekarjo, D., Soekirman, Solon, J. A., Theary, C., \& Wasantwisut, E. (2013). Key strategies to further reduce stunting in Southeast Asia: lessons from the ASEAN countries workshop. Food and nutrition bulletin. https:// doi.org/10.1177/15648265130342s103

El-Fatah, N. K., \& Abu-Elenin, M. M. (2019). Prevalence of Stunting, Overweight and Obesity among Egyptian Primary School Children in Behera Governorate. Food and Public Health, 84-93.

Fitri, Y., Al Rahmad, A. H., Suryana, S., \& Nurbaiti, N. (2020). Pengaruh penyuluhan gizi tentang jajanan tradisional terhadap peningkatan pengetahuan dan perilaku jajan anak sekolah. AcTion: Aceh Nutrition Journal, 5(1), 13-18. https://doi.org/10.30867/action.v5i1.186

Hastuti, A. P., \& Hanim, M. (2018). Pengaruh Family Empowerment Modified Model terhadap Tingkat Family Empowerment, Pola Makan dan Status Nutrisi pada Anak Usia Sekolah. Hesti Wira Sakti, 2(6).

John-Akinola, Y. (2014). Children and Parents' Participation: Socio-ecological Perspectives On Health Promotion In Schools. University of Ireland.

Morris, S., Cogill, B., \& Uauy, R. (2008). Effective International Action Against Undernutrition: Why has it Proven so Difficult and what can be done to Accelerate Progress? Maternal and Child Undernutrition. The Lancet.

Niman, S. (2017). Promosi dan Pendidikan Kesehatan. Trans Info Media.

Notoatmodjo, S. (2010). Ilmu Perilaku Kesehatan. Rineka Cipta.

Oktaviani, H., \& Sunarti, S. (2020). Pengaruh Media Puzzle Terhadap Pengetahuan dan Sikap Tentang Gizi Seimbang pada Siswa Kelas IVdi SD Negeri 001 Samarinda Seberang. Borneo Student Research, 1(2), 725-729.

Paz-Soldán, V. A., Morrison, A. C., Lopez, J. J. C., Lenhart, A., Scott, T. W., Elder, J. P., Sihuincha, M., Kochel, T. J., Halsey, E. S., Astete, 
H., \& McCall, P. J. (2015). Dengue knowledge and preventive practices in Iquitos, Peru. American Journal of Tropical Medicine and Hygiene, 93(6), 1330-1337. https:// doi.org/10.4269/ajtmh.15-0096

Pusat Promosi Kesehatan. (2008). Promosi Kesehatan di Sekolah. Kementerian Kesehatan.

Pusdatin Kemenkes. (2018). Situasi balita pendek (stunting) di Indonesia. Kementerian Kesehatan RI.

Sefrina, L. R., \& Elvandari, M. (2020). Pelatihan Penilaian Status Gizi Pada Guru Dalam Rangka Deteksi Siswa Stunting Di Sekolah Dasar. Dharmakarya, 9(1), 4-7. https:// doi.org/10.24198/dharmakarya.v9i1.24854

Suryawan, N. (2019). Efektivitas Penyuluhan Pencegahan Thalassemia Di SMPN 1 dan SMPN 2 Tempuran Kabupaten Karawang. Dharmakarya, 8(1). https://doi.org/10.24198/ dharmakarya.v8i1.19820

WHO. (2018). Reducing stunting in children: equity considerations for achieving the Global Nutrition Targets 2025. In Equity considerations for achieving the Global Nutrition Targets 2025. 